\begin{tabular}{|c|c|c|}
\hline & $\begin{array}{l}\text { International Journal of Current Research in } \\
\text { Biosciences and Plant Biology }\end{array}$ & $y=$ \\
\hline & Volume 6 • Number 11 (November-2019) • ISSN: 2349-8080 (Online) & \\
\hline $\begin{array}{l}\text { EXCELLEN } 1 \\
\text { PUBLISHERS }\end{array}$ & Journal homepage: www.ijcrbp.com & \\
\hline
\end{tabular}

\title{
Phosphorus, nitrogen, sulfur, boron and zinc fertilization effects on soybean yield and quality
}

\author{
Inés C. Davérède*, Fernando H. Míguez, Agustina Ailín Borracci \\ Engineering and Agricultural Sciences College, Universidad Católica Argentina, Buenos Aires, \\ C1107AAZ, Argentina \\ *Corresponding author; e-mail: inesdaverede@gmail.com
}

\begin{tabular}{|c|c|}
\hline Article Info & \multirow{5}{*}{ 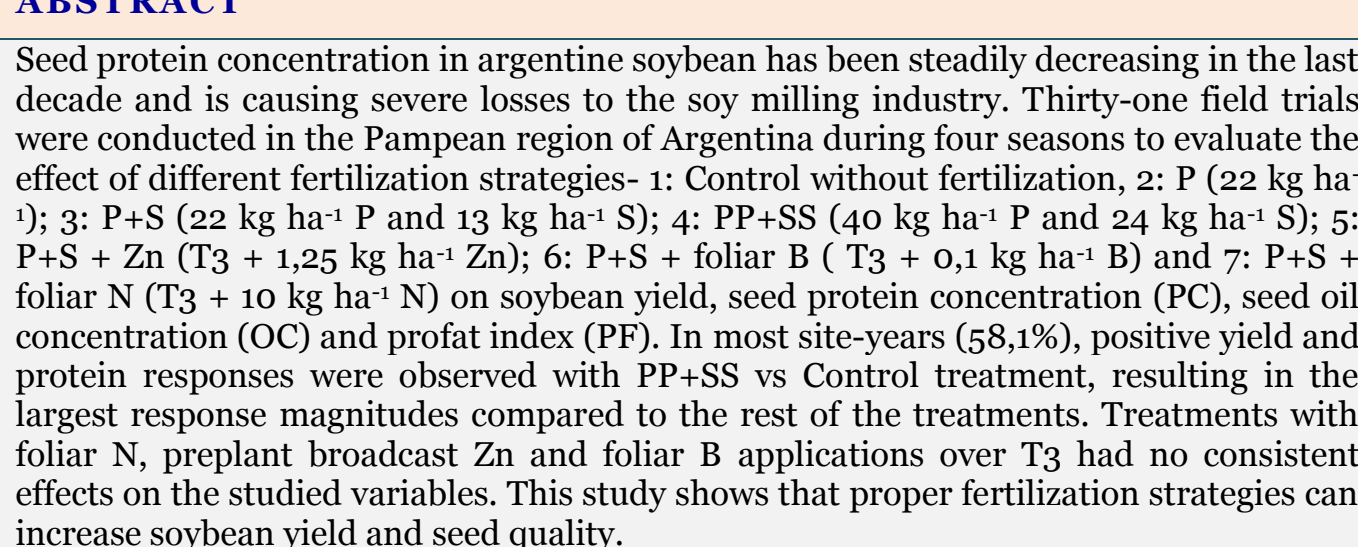 } \\
\hline $\begin{array}{l}\text { Date of Acceptance: } \\
\text { o3 November } 2019\end{array}$ & \\
\hline $\begin{array}{l}\text { Date of Pub } \\
\text { o6 Novembe }\end{array}$ & \\
\hline Keywords & \\
\hline $\begin{array}{l}\text { Glycine max } \\
\text { Oil } \\
\text { Profat } \\
\text { Protein }\end{array}$ & \\
\hline
\end{tabular}

\section{Introduction}

Soybean industrial quality is mainly determined by its protein (PC) and oil concentrations (OC); $\mathrm{PC}$ is the protein content relative to other seed components such as oil and carbohydrates. The soybean milling industry competitiveness depends on soybean meal PC which must meet international standards to qualify as high protein and avoid price discounts and even rejections by customers. Argentine soybean PC has been steadily decreasing during the last decade causing severe losses to the milling industry (Cuniberti and Herrero, 2018).

Oil and protein synthesis and build-up processes in soybean depend mainly on the genotype, the radiative and thermal environment during the grain filling stage, nutrient availability and crop yield (Thibodeau et al., 1975; Dardanelli et al. 2006; Rotundo and Westgate, 2009; Kane et al. 1997; Martinez and Cordone, 2015).Grain OC and PC are usually inversely related (Martínez and Cordone, 2015; Haq and Mallarino, 2005).

Soybean seed PC usually ranges between 33 and $42 \%$, and its meal is one of the feeds with the highest protein value. A substantial portion of nitrogen $(\mathrm{N})$ requirements in soybeans are met through soil absorption and nitrogen biological fixation (BFN) (Ronis et al., 1985). 
In most cases, legume plants that obtain $\mathrm{N}$ through $\mathrm{BFN}$ have higher phosphorus (P), potassium (K) and sulphur (S) requirements than those plants that only depend on soil N (Israel, 1987; Sulieman et al., 2013).

Legumes are particularly sensitive to $\mathrm{P}, \mathrm{K}$ and $\mathrm{S}$ deficiency. Divito and Sadras (2014) explain that these nutrients have a direct effect over BFN because they regulate multiple biological processes such as rhizobia growth and nodule formation and functionality. Pampean soils rarely lack $\mathrm{K}$ (Correndo et al., 2012; Sillanpaa, 1982) therefore, historically, this nutrient has not been included in field trials as a treatment. In fact, Prystupaet al. (2004) observed no maize yield response to $\mathrm{K}$ fertilization.

Numerous studies have shown soybean yield responses to $\mathrm{P}$ application when available $\mathrm{P}$ soil contents were low (Gutierrez Boem et al., 2006; Díaz-Zorita, 1999; Fontanetto et al., 2009; Ferraris et al., 2015; García et al., 2009; Aulakh et al., 1990). Sucunzaet al.(2018) suggested a yield response threshold of $14 \mathrm{mg} \mathrm{kg}^{-1}$ available soil $\mathrm{P}$ (Bray I). Regarding S, Carciochiet al.(2015)proposed a decision tree that suggests crop response to $\mathrm{S}$ fertilization with a threshold of $40 \mathrm{~kg} \mathrm{ha}^{-1}$ (approximately $5 \mathrm{mg} \mathrm{kg}^{-1}$ ) of $\mathrm{S}_{-} \mathrm{SO}_{4}$ in a o-0,60 m depth, in soils with coarse texture, long agricultural history, low organic matter content, no-till sowing, no fallow and a water table without sulphates. Martinez and Cordone (2015) and Aulakh et al. (1990)reported positive effects of $\mathrm{P}$ and $\mathrm{S}$ fertilization on soybean grain PC. In contrast, Haq and Mallarino (2005) observed that $\mathrm{P}$ and $\mathrm{K}$ fertilization increased soybean yield but had little, infrequent and inconsistent effects on PC and OC. As Aulakh et al. (1990) explain, P is involved in the synthesis of phospholipids while $S$ is required for oil storage organs which are proteinous in nature.

Under high yielding environments, $\mathrm{BFN}$ and $\mathrm{N}$ provided by soil organic matter could be insufficient to meet grain $\mathrm{N}$ demand during the filling stage. Foliar fertilization during late reproductive stages, when the number of pods has already been fixed, could theoretically increase $\mathrm{N}$ absorption, yield and PC. Moreira et al. (2017) observed $6.1 \%$ yield response when applying $10 \mathrm{~kg}$
$\mathrm{N}$ ha ${ }^{-1}$ at soybean growth stages $\mathrm{R}_{3}$ and $\mathrm{R} 4$. On the other hand, Salvagiotti et al. (2008) observed that foliar $\mathrm{N}$ fertilization increased yields from 130 to $620 \mathrm{~kg} \mathrm{ha}^{-1}$ under high yielding environments (over 4,5 $\mathrm{Mg} \mathrm{ha}^{-1}$ ). Barker and Sawyer (2005) found no response in soybean grain PC with soil $\mathrm{N}$ fertilization and foliar $\mathrm{N}$ fertilization in early reproductive crop stages. Moreira et al. (2017) obtained similar results as they did not find any effects of foliar $\mathrm{N}$ fertilization on PC and OC.

Micronutrients play an essential role in the plant metabolism (1995). Many studies observed that soybean yields and grain PC increased when B, Zn and $\mathrm{Mg}$ micronutrients were applied (Aytac et al., 2007; Bellaloui et al., 2010; Ghasemian et al., 2010; Panse, 2010).

The aim of this study was to evaluate the effect $P$, $\mathrm{N}, \mathrm{S}, \mathrm{B}$ and $\mathrm{Zn}$ fertilization on soybean yield and grain composition in order to assess a fertilization strategy that could increase PC and yield simultaneously.

\section{Materials and methods}

\section{Experimental design}

The experimental design was a randomized complete block with four repetitions, replicated in 31 site-years in the Pampean region of Argentina. Soybean varieties with maturity groups III to $\mathrm{V}$ were planted at a density of 300.000 seeds ha-1 on $3 \times 5 \mathrm{~m}$ experimental units (Table 1). Seeds were treated with fungicides and inoculated with Bradyrhizobium japonicum (except at one siteyear where they were not inoculated). Weeds, pests and diseases were monitored and controlled when necessary. Soil samples were taken before planting at $0-0,20 \mathrm{~m}$ and $0,20-0,40 \mathrm{~m}$ depths to determine: pH (Peech, 1965), moisture, electric conductivity (Allison et al., 1977), organic matter (Nelson and Sommers, 1982), exchangeable cations (Richter et al., 1982), extractable P (Bray and Kurtz, 1945) and colorimetric quantification (Murphy and Riley, 1962), extractable Zn (Lindsay and Norvell, 1978), cations exchange capacity, nitrates (Marbán, 2005) and sulphates -ammonium acetate extraction at $\mathrm{pH} 5$, soil:solution ratio 1:5 with one-hour agitation and turbidimetric quantification (Lisle et al., 1994) (Table 1). 
Table 1. Soybean varieties, soil type, texture, $\mathrm{pH}$, organic matter percentage (MO\%), P-Bray and other soils variables in 31 site-years in the Pampean region in Argentina during years 13/14, 14/15, 15/16 and 16/17.

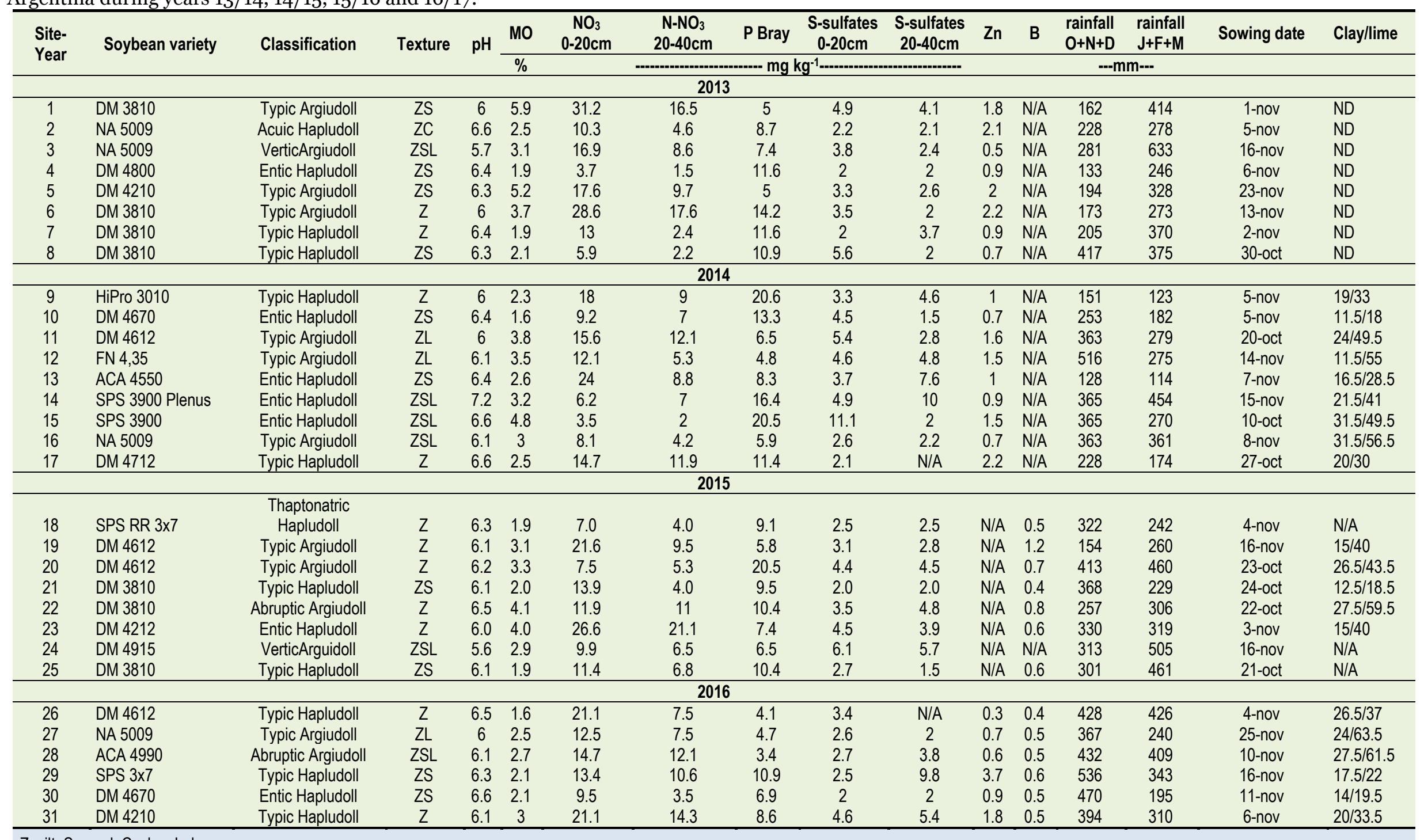

Z: silt; S: sand; C: clay; L: loam 
The following treatments were repeated for four years: 1. Control without fertilization (T), 2. a replacement $\mathrm{P}$ rate of $22 \mathrm{~kg} \mathrm{ha}^{-1}$-restores the $\mathrm{P}$ exported with the soybean seed for an estimated 4 $\mathrm{Mg} \mathrm{ha}^{-1}$ grain yield-, 3. treatment $2+13 \mathrm{~kg} \mathrm{ha}^{-1}$ of S at a replacement rate, and a double rate of $40 \mathrm{~kg} \mathrm{P}$ $\mathrm{ha}^{-1}+24 \mathrm{~kg} \mathrm{~S} \mathrm{ha}^{-1}(\mathrm{PP}+\mathrm{SS}$; Table 2). During the first year (2013) and one month before planting, monoammonium phosphate (Grade: 11: 22:0) was broadcast as a source of $\mathrm{P}$ and Microessentials ${ }^{\circledR}$ was broadcast as a source of $\mathrm{P}$ and $\mathrm{S}$ (Grade: 12: 18: 0:10S). In this case, a base of $8 \mathrm{~kg} \mathrm{~N} \mathrm{ha}^{-1}$ was broadcast as urea in the control treatment to balance the $\mathrm{N}$ rates of the rest of the treatments. In the following years, calcium triple superphosphate (Grade: 0:20:0) was broadcast as the source of $\mathrm{P}$,and simple superphosphate (Grade: 0:9:0:14S) was broadcast as the source of $\mathrm{P}$ and $\mathrm{S}$.

Table 2. Nutrient rates applied to soybean crops for each treatment in 31 field trials in the Pampean region in Argentina.

\begin{tabular}{|c|c|c|c|c|c|c|}
\hline Treatments & $\mathbf{N}$ & $\mathbf{P}$ & $\mathbf{S}$ & $\mathbf{Z n}$ & $\mathbf{B}$ & Trial Year \\
\hline \multicolumn{7}{|c|}{------------------- kg ha-1 ------------------- } \\
\hline Control (T) & & 0 & 0 & & & $2013,2014,2015,2016$ \\
\hline $\mathrm{P}$ & & 22 & 0 & & & $2013,2014,2015,2016$ \\
\hline $\mathrm{P}+\mathrm{S}$ & & 22 & 13 & & & $2013,2014,2015,2016$ \\
\hline $\mathrm{PP}+\mathrm{SS}$ & & 40 & 24 & & & $2013,2014,2015,2016$ \\
\hline Foliar N & 10 & & & & & $2013,2014,2015$ \\
\hline Foliar B & 0.3 & & & & 0.1 & $2013,2014,2015$ \\
\hline $\mathrm{Zn}$ & & 22 & 13 & 1.25 & & 2013,2014 \\
\hline
\end{tabular}

Besides the aforementioned treatments, foliar $\mathrm{N}$ (Foliarsol $\mathrm{U}^{\circledR}$ ), foliar $\mathrm{B}$ (Foliarsol $\mathrm{B}^{\circledR}$ ) and $\mathrm{Zn}$ were applied at the typical rates used in the literature. Regarding foliar N, during the first year, $25 \mathrm{~kg} \mathrm{~N}$ ha $^{-1}$ were sprayed at R5[40], causing leaf burning in most site-years, so in the following years, a rate of $10 \mathrm{~kg} \mathrm{~N} \mathrm{ha}^{-1}$ was sprayed. Foliar B was sprayed at R2 at a rate of $100 \mathrm{~g} \mathrm{~B} \mathrm{ha}^{-1}$ (Fontanetto et al., 2009) during the last three years with a base fertilization of $\mathrm{P}$ and $\mathrm{S}$ (same as the rest of treatments), simulating a producer who adds technologies.

As for $\mathrm{Zn}$ fertilization, during two cropping years, $1.25 \mathrm{~kg} \mathrm{Zn} \mathrm{ha-1}$ were broadcast in a blend with $\mathrm{P}$ and S (Microessentials $Z n \AA$ 12: 17: 0: 10S: $1 \mathrm{Zn}$ ) before planting.

At the crop commercial maturity stage, $2 \mathrm{~m}^{2}$ of each plot were harvested by cutting the plants with garden scissors at ground level. Plants were sun-dried and threshed with a stationary thresher. Grain moisture was measured with a hygrometer and samples were weighed to calculate yield at a moisture of $13 \%$. Then three groups of 200 seeds were counted and weighed separately to calculate seed weight which was also expressed with $13 \%$ moisture.

\section{Analytical methods}

Five-hundred-gram seed samples from each plot were analysed with infrared spectrophotometry for PC and OC; results were expressed on a dry matter basis. The profat index (PF) indicates the industrial yield in the soybean crushing process and results from adding protein and oil percentages.

\section{Statistical analysis}

A mixed model which considered heterogeneous variances among site-years was used for the statistical analyses to find differences among treatments for yield, PC, OC and PF (SAS/STAT, 1992). Site-years were considered random factors while fertilization treatments were considered fixed factors. Pre-planned contrasts were performed to calculate the differences between treatments for each variable and their statistical significance, and to determine the standard errors for average values which were included in the figures. An alpha value of 0.1 was used to detect significant differences. 


\section{Results}

\section{$\mathbf{P}, \mathbf{P}+\mathbf{S}$ simple and double rates}

Phosphorus and $\mathrm{P}+\mathrm{S}$ treatments were repeated for four years; therefore, a four-year variance analysis was conducted. Each experiment was numbered by its year and site-year (alphabetically, data not shown) because not every site-year was repeated in all four years (Table 1).

\section{Yield and yield components}

The main effect of the broadcast pre-plant fertilization treatments was significant for yield and its components $(\mathrm{P}<0,1)$ while site-year $\mathrm{x}$ treatment interaction was not $(\mathrm{P}=0,343)$; therefore, treatment values were averaged over all site-years (Table 3). The control treatment yields averaged $4 \mathrm{Mg} \mathrm{ha}^{-1}$ across years and the yield response to $22 \mathrm{~kg} \mathrm{P}$ ha $^{-1}$ averaged $261 \mathrm{~kg} \mathrm{ha}^{-1}$ ( $\mathrm{P}<0,001)$. Adding $13 \mathrm{~kg} \mathrm{~S} \mathrm{ha}^{-1}$ to the same $\mathrm{P}$ base increased yields another $163 \mathrm{~kg} \mathrm{ha}^{-1}(\mathrm{P}=0,034)$, and a double rate of $\mathrm{P}+\mathrm{S}$ increased yields $126 \mathrm{~kg}$ $\mathrm{ha}^{-1}$ over the simple $\mathrm{P}+\mathrm{S}$ rate $(\mathrm{P}=0,086)$. The yield responses were partly explained by a $5.3 \%$ increase in grain number caused by $\mathrm{P}$ application, and to a lesser extent to a $\mathbf{1 . 7 \%}$ increase in seed weight caused by the combined $\mathrm{P}+\mathrm{S}$ application (Table 3).

Table 3. Yield, seed weight, grain number and profat index of soybean seed for four fertilization treatments: T: control without fertilization; P: $22 \mathrm{~kg} \mathrm{P}^{-1}$; P+S: $22 \mathrm{~kg} \mathrm{P}^{-1}$ and $13 \mathrm{~kg} \mathrm{~S}^{-1}$; PP+SS: $40 \mathrm{~kg} \mathrm{P}^{-1} \mathrm{ha}^{-1}$ and $24 \mathrm{~kg} \mathrm{~S}^{-1}$ in the Pampean region in Argentina during years 13/14, 14/15, 15/16 y 16/17. Different letters show significant differences for p-value $<0.1$ within each variable.

\begin{tabular}{lllllllllll}
\hline Parameters & T & & P & & P+S & & PP+SS & & SE \\
\hline Yield (Mg ha-1) & 4 & d & 4.3 & c & 4.5 & b & 4.6 & a & 0.06 \\
Seed weight $(\mathrm{g}) \times 1000$ & 169 & c & 170 & bc & 172 & ab & 173 & a & 0.88 \\
Number of grains m-2 & 2427 & c & 2556 & b & 2628 & ab & 2692 & a & 54 \\
Profat index (\%) & 60.28 & c & 60.41 & b & 60.55 & a & 60.56 & a & 0.065 \\
\hline SE=standard error & & & & & & & & &
\end{tabular}

\section{Protein concentration}

Site-year $\mathrm{x}$ treatment interaction was significant for PC; therefore, results are shown for each siteyear (Table 4). Protein concentration averaged $36.7 \%$ among control treatments, while it averaged $36.9 \%$ for $\mathrm{P}, 37.0 \%$ for $\mathrm{P}+\mathrm{S}$ and $37.1 \%$ for $\mathrm{PP}+\mathrm{SS}$ treatments. In four site-years, $\mathrm{P}$ application increased $\mathrm{PC}$ significantly by 1.6 percentage points (p.p.); P+S application increased PC at four siteyears by 0.9 p.p. while the double rate application (PP+SS) increased PC at ten site-years by 1,5 p.p. over $\mathrm{T}$. At one site-year, the PC response was negative for $\mathrm{P}$ and $\mathrm{P}+\mathrm{S}$ applications (Table 4).

Yield and PC responses were plotted on a graph. Yield response was plotted on the $\mathrm{X}$-axis and the $\mathrm{PC}$ response was plotted on the Y-axis (Fig. 1). At 41.9\% of the site-years, positive yield and protein responses to $\mathrm{P}$ application were observed, averaging $217 \mathrm{~kg} \mathrm{ha}^{-1}(\mathrm{SE}=263)$ and 0,22 p.p.
( $\mathrm{SE}=0.36$, Fig. $1 \mathrm{~A}$ ), respectively. In addition, at $41.9 \%$ of the site-years, positive yield and protein responses to $\mathrm{S}$ application (with a $\mathrm{P}$ base) were observed, averaging $127 \mathrm{~kg} \mathrm{ha}^{-1}(\mathrm{SE}=400)$ and 0.17 p.p. ( $\mathrm{SE}=0.36$; Fig. 1D). Application of $\mathrm{P}+\mathrm{S}$ and $\mathrm{PP}+\mathrm{SS}$ compared to $\mathrm{T}$ determined that $51,6 \%$ and $58.1 \%$ of the site-years, respectively, had positive yield and $\mathrm{PC}$ responses (quadrant,++ ; Fig. $1 \mathrm{~B}$ and C). Yield average response on the positive quadrant was $314 \mathrm{~kg} \mathrm{ha}^{-1}(\mathrm{SE}=332)$ for $\mathrm{P}+\mathrm{S}($ Fig. $1 \mathrm{~B})$ and 431 $\mathrm{kg} \mathrm{ha}^{-1}(\mathrm{SE}=395)$ for $\mathrm{PP}+\mathrm{SS}$ compared to $\mathrm{T}$ (Fig. 1C) while $\mathrm{PC}$ average response for the same quadrant was 0,31 p.p. $(\mathrm{SE}=0.4)$ for $\mathrm{P}+\mathrm{S}($ Fig. $1 \mathrm{~B})$ and 0.48 p.p. (SE=0.5) for PP+SS (Fig. 1C).

\section{Oil concentration}

Site-year $\mathrm{x}$ treatment interaction was significant for OC $(\mathrm{P}=0.072)$. Oil concentration increased with the simple and double $\mathrm{P}+\mathrm{S}$ rates in $16 \%$ of the siteyears, but in $80 \%$ of the site-years, the response 
was negative. In one site-year only, there was a positive response to $\mathrm{P}$ application (Table 5). Negative responses averaged -0.8, -0.5 y -1.4 p.p. with $\mathrm{P}, \mathrm{P}+\mathrm{S}$ and $\mathrm{PP}+\mathrm{SS}$ treatments, respectively.
The OC decrease was associated with a significant PC increase (Pearson Correlation Coefficient $\mathrm{r}=-0.80 ; \mathrm{P}<0.0001)$. In five site-years, $\mathrm{PC}$ increased without an OC decrease.

Table 4. Protein concentration in soybean seed for four fertilization treatments T: control without fertilization; P: 22

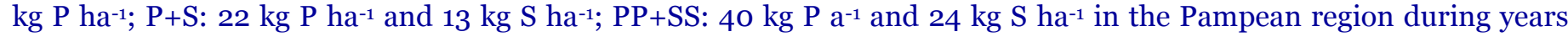
$13 / 14,14 / 15,15 / 16$ and 16/17. Different letters show significant differences for $p$-value $<0.1$ within each variable. $S E=$ standard error.

\begin{tabular}{|c|c|c|c|c|c|c|c|c|c|}
\hline \multirow{2}{*}{$\begin{array}{l}\text { Site } \\
1\end{array}$} & \multicolumn{2}{|c|}{ Control } & \multicolumn{2}{|l|}{$\mathbf{P}$} & \multicolumn{2}{|l|}{$\mathbf{P}+\mathbf{S}$} & \multicolumn{2}{|c|}{$\mathbf{P P}+\mathbf{S S}$} & \multirow{2}{*}{$\begin{array}{l}\text { SE } \\
0.2717\end{array}$} \\
\hline & 36.4 & $\mathrm{a}$ & 35.4 & bc & 35.1 & $\mathrm{bc}$ & 35.8 & $\mathrm{abc}$ & \\
\hline 2 & 39.1 & & 38.8 & & 38.8 & & 39.5 & & 0.2717 \\
\hline 3 & 39.3 & & 39.4 & & 39.7 & & 39.1 & & 0.2717 \\
\hline 4 & 38.1 & & 37.5 & & 38.0 & & 37.9 & & 0.2717 \\
\hline 5 & 34.5 & $\mathrm{~b}$ & 34.7 & $\mathrm{~b}$ & 34.1 & $\mathrm{~b}$ & 35.9 & $\mathrm{a}$ & 0.2717 \\
\hline 6 & 37.1 & & $37 \cdot 7$ & & 37.7 & & 38.3 & & 0.2717 \\
\hline 7 & 35.8 & & 35.0 & & 35.6 & & 35.1 & & 0.2717 \\
\hline 8 & $35 \cdot 5$ & & $35 \cdot 9$ & & 36.0 & & $35 \cdot 7$ & & 0.2717 \\
\hline 9 & 43.4 & $\mathrm{c}$ & 46.3 & $\mathrm{a}$ & 43.5 & $\mathrm{c}$ & $45 \cdot 3$ & $\mathrm{~b}$ & 0.2353 \\
\hline 10 & $37 \cdot 3$ & $\mathrm{~b}$ & 38.6 & $\mathrm{a}$ & 38.1 & $\mathrm{ab}$ & 38.7 & $\mathrm{a}$ & 0.2717 \\
\hline 11 & 34.9 & & 35.0 & & 34.7 & & 34.7 & & 0.2717 \\
\hline 12 & 38 & & 37 & & 38 & & 38 & & 0.2688 \\
\hline 13 & $35 \cdot 7$ & $\mathrm{~b}$ & 36.5 & $\mathrm{ab}$ & 36.3 & $\mathrm{ab}$ & 37.4 & $\mathrm{a}$ & 0.2717 \\
\hline 14 & 36.9 & & 36.4 & & 36.6 & & 36.9 & & 0.2717 \\
\hline 15 & 37 & & 37 & & 37 & & 37 & & 0.2688 \\
\hline 16 & 36.8 & & 36.7 & & 37.5 & & 37.5 & & 0.2717 \\
\hline 17 & 36.2 & & $35 \cdot 3$ & & $35 \cdot 9$ & & $35 \cdot 7$ & & 0.2717 \\
\hline 18 & 34.7 & $\mathrm{~b}$ & 36.3 & a & 36.3 & $\mathrm{a}$ & 35.8 & $\mathrm{a}$ & 0.2493 \\
\hline 19 & 34 & & 35 & & 35 & & 35 & & 0.2353 \\
\hline 20 & 36 & & 36 & & 36 & & 36 & & 0.2353 \\
\hline 21 & 39.6 & & 40.4 & & 40.4 & & 39.8 & & 0.2353 \\
\hline 22 & 38.6 & & 38.2 & & 37.7 & & 38.0 & & 0.2717 \\
\hline 23 & 37.5 & $\mathrm{~b}$ & 38.0 & $a b$ & 38.2 & $a b$ & 38.7 & $\mathrm{a}$ & 0.2353 \\
\hline 24 & 34.4 & & 34.4 & & 35.5 & & 35.0 & & 0.2353 \\
\hline 25 & 34.7 & & 34.5 & & 34.7 & & 34.6 & & 0.2353 \\
\hline 26 & 33.2 & $\mathrm{~b}$ & 34.0 & b & 35.2 & $\mathrm{a}$ & $35 \cdot 5$ & $\mathrm{a}$ & 0.2353 \\
\hline 27 & 37.0 & $\mathrm{~b}$ & 37.2 & b & 38.0 & $\mathrm{a}$ & 37.4 & $\mathrm{a}$ & 0.2353 \\
\hline 28 & 34.9 & $\mathrm{c}$ & 36.0 & $\mathrm{~b}$ & 36.4 & $\mathrm{bc}$ & 37.0 & $\mathrm{c}$ & 0.2353 \\
\hline 29 & 36.1 & $\mathrm{~b}$ & $35 \cdot 7$ & $\mathrm{~b}$ & 36.6 & $\mathrm{~b}$ & 37.1 & $\mathrm{a}$ & 0.2493 \\
\hline 30 & 36.4 & & 36.5 & & 36.7 & & 36.0 & & 0.2353 \\
\hline 31 & 38.2 & & 38.1 & & 38.0 & & 37.7 & & 0.2353 \\
\hline
\end{tabular}



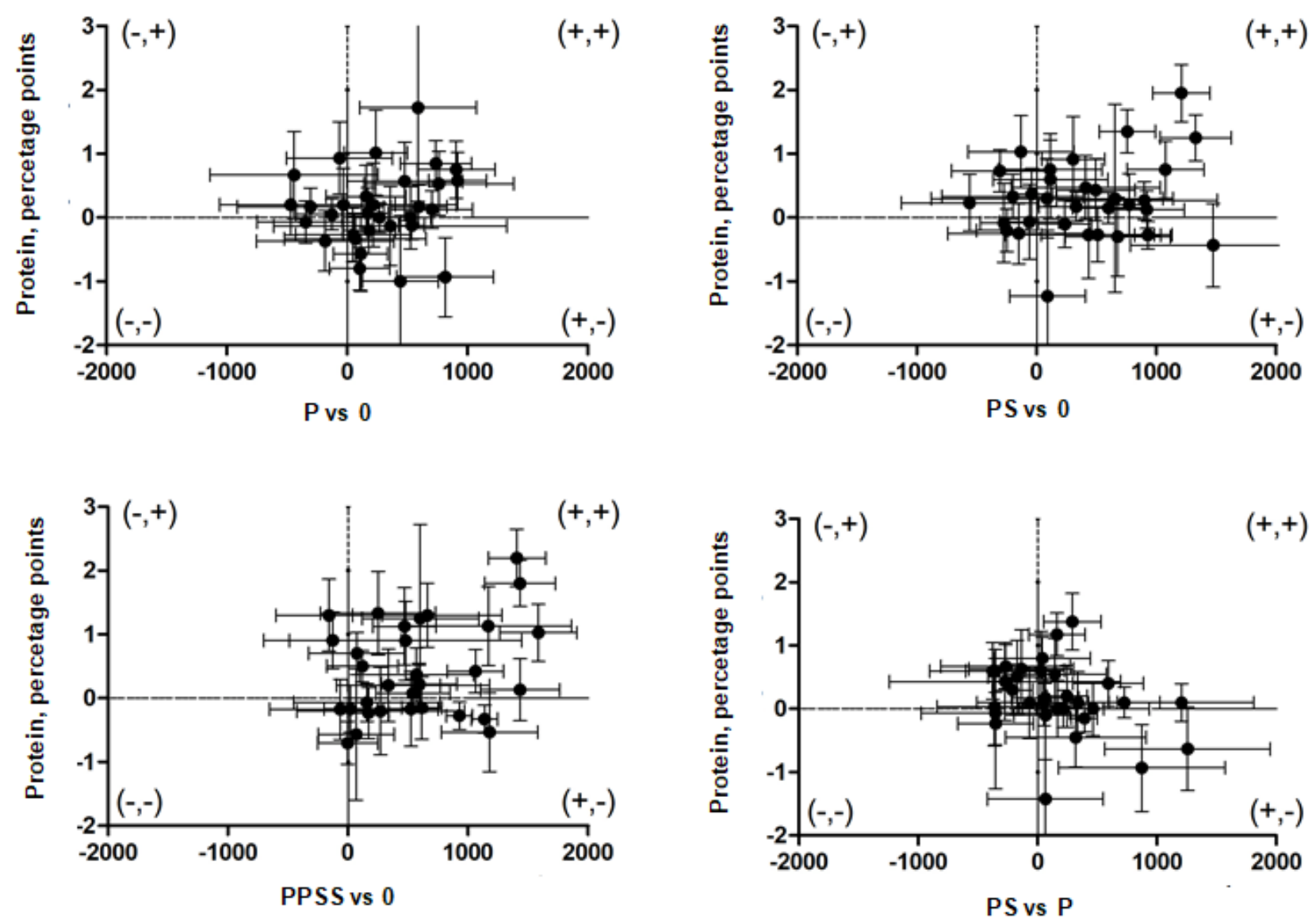

Fig. 1: Comparison of the relationship between yield ( $\left.\mathrm{kg} \mathrm{ha}^{-1}\right)$ and protein (percentage points) response for different treatments: P vs o (22 kg P vs Control), P+S vs o (22 kg P and $13 \mathrm{~kg} \mathrm{~S}$ vs Control), PP+SS vs o (40 kg P and $24 \mathrm{~kg} \mathrm{~S}$ vs Control) and P+S vs P (22 kg P and $13 \mathrm{~kg} \mathrm{~S}$ vs $22 \mathrm{~kg} \mathrm{P}$ ) in the Pampean region in Argentina during years 13/14, 14/15, 15/16 and 16/17. Each point represents a different location with its standard error.

\section{Profat}

The fertilizer treatment main effect was significant for $\mathrm{PF} \quad(\mathrm{P}<0.1)$. There was no treatment $\mathrm{x}$ site-year interaction for $\mathrm{PF}$; therefore, only main effects are shown (Table 3). Phosphorus, $\mathrm{P}+\mathrm{S}$ and $\mathrm{PP}+\mathrm{SS}$ treatments increased PF by $0.16,0.29$ and 0.34 p.p., respectively, compared to the control treatment, without significant differences between the simple and double $\mathrm{P}$ and $\mathrm{S}$ rates.

\section{Zn fertilization effects}

Preplant broadcast $\mathrm{Zn}$ applications had no significant effects on the measured variables despite the wide range of soil-available $\mathrm{Zn}$ concentrations ( 0.3 to $3.7 \mathrm{mg} \mathrm{kg}^{-1}$ ).

\section{Foliar $\mathbf{N}$ application at $\mathbf{R} 5$}

Site-year $\mathrm{x}$ foliar $\mathrm{N}$ treatment interactions were significant for yield and protein. In some siteyears, foliar $\mathrm{N}$ application increased yield and PC, but in others, it had no effect or decreased them (Fig. 2). There was a tendency of an average decrease of $2.25 \mathrm{~g}$ in seed weight $(\mathrm{P}=0.12)$ with 10 $\mathrm{kg}$ foliar $\mathrm{N} \mathrm{ha}^{-1}$ applied at $\mathrm{R} 5$. Oil concentration and $\mathrm{PF}$ were not affected by foliar $\mathrm{N}$ application.

\section{Foliar B application at R2}

There was no interaction between foliar B treatment and site-year for yield and seed weight. Foliar B application tended to increase seed weight by $2.37 \mathrm{~g}(\mathrm{P}=0.11)$, but this slight increase was not enough to produce a significant yield increase. 
Table 5. Oil concentration in soybean seed for four fertilization treatments T: control without fertilization; P: $22 \mathrm{~kg} P$ ha-1; P+S: $22 \mathrm{~kg} \mathrm{P} \mathrm{ha}^{-1}$ and $13 \mathrm{~kg} \mathrm{~S}^{-1}$; PP+SS: $40 \mathrm{~kg} \mathrm{P} \mathrm{ha}^{-1}$ and $24 \mathrm{~kg} \mathrm{~S}^{-1}$ in the Pampean region in Argentina during years 13/14, 14/15, 15/16 and 16/17. Different letters show significant differences for a p-value $<0.1$ within each variable. $\mathrm{SE}=$ standard error.

\begin{tabular}{|c|c|c|c|c|c|c|c|c|}
\hline Site & Control & $\mathbf{P}$ & & $\mathbf{P}+\mathbf{S}$ & & $\mathbf{P P}+\mathbf{S S}$ & & SE \\
\hline 1 & 23.2 & 23.8 & & 23.7 & & 23.5 & & 0.1322 \\
\hline 2 & 21.7 & 21.7 & & 21.7 & & 21.7 & & 0.1322 \\
\hline 3 & 21.7 & 21.7 & & 21.7 & & 21.9 & & 0.1322 \\
\hline 4 & 24.3 & 24.1 & & 23.9 & & 24.2 & & 0.1322 \\
\hline 5 & $24 \cdot 3$ & 24.4 & & 24.6 & & 24.4 & & 0.1322 \\
\hline 6 & 22.4 & 22.1 & & 22.2 & & 22.2 & & 0.1322 \\
\hline 7 & 24.1 & 24.4 & & 24.1 & & 24.2 & & 0.1322 \\
\hline 8 & 24.4 & 24.4 & & 24.5 & & 24.5 & & 0.1322 \\
\hline 9 & 18.1 & 16.6 & $\mathrm{c}$ & 17.4 & b & 16.9 & $\mathrm{~b}$ & 0.1145 \\
\hline 10 & 24.5 & 23.5 & $\mathrm{~b}$ & $24 \cdot 3$ & $\mathrm{a}$ & 23.0 & $\mathrm{~b}$ & 0.1322 \\
\hline 11 & 24.8 & 25.0 & & 25.0 & & 25.2 & & 0.1322 \\
\hline 12 & 23.3 & 23.1 & & 22.9 & & 23.0 & & 0.1301 \\
\hline 13 & 24.7 & 24.7 & a & $24 \cdot 7$ & a & 23.4 & $\mathrm{~b}$ & 0.1322 \\
\hline 14 & 23.2 & 23.9 & & 23.9 & & 23.8 & & 0.1322 \\
\hline 15 & 22.7 & 22.8 & & 22.8 & & 22.7 & & 0.1301 \\
\hline 16 & 23.8 & 23.6 & & $23 \cdot 3$ & & 23.5 & & 0.1322 \\
\hline 17 & 21.7 & 23.0 & $\mathrm{a}$ & 22.9 & $\mathrm{ac}$ & 22.8 & $\mathrm{a}$ & 0.1322 \\
\hline 18 & 24.0 & 23.8 & & 23.8 & & 23.2 & & 0.1232 \\
\hline 19 & 23.9 & 23.7 & & 23.6 & & 23.6 & & 0.1145 \\
\hline 20 & 23.6 & 23.9 & & 23.9 & & 23.9 & & 0.1145 \\
\hline 21 & 22.2 & 21.8 & & 21.9 & & 22.2 & & 0.1145 \\
\hline 22 & 24.4 & 24.1 & & 24.4 & & 24.6 & & 0.1397 \\
\hline 23 & 22.7 & 22.5 & & 22.7 & & 22.4 & & 0.1145 \\
\hline 24 & 23.6 & 23.6 & & 23.5 & & 23.3 & & 0.1145 \\
\hline 25 & 23.8 & 23.9 & & 23.7 & & 23.8 & & 0.1145 \\
\hline 26 & 27.0 & 26.2 & b & $25 \cdot 7$ & bc & $25 \cdot 5$ & $\mathrm{c}$ & 0.1145 \\
\hline 27 & 23.4 & 23.2 & & 22.7 & & 23.2 & & 0.1145 \\
\hline 28 & 25.7 & $25 \cdot 3$ & & $25 \cdot 3$ & & 25.0 & & 0.1145 \\
\hline 29 & 23.9 & 24.0 & & 24.1 & & 24.0 & & 0.1232 \\
\hline 30 & 24.5 & 24.2 & & 24.4 & & 24.3 & & 0.1145 \\
\hline 31 & 24.8 & 24.9 & & 25.0 & & 25.0 & & 0.1145 \\
\hline
\end{tabular}

Regarding seed number, results were inconsistent. There was a significant interaction between the effect of foliar B with the site-year. At one site-year, seed number increased by 218 seeds $\mathrm{m}^{-2}(\mathrm{P}=0.1)$ while at a different site-year, it decreased by 400 seeds $\mathrm{m}^{-2}(\mathrm{P}=0.023)$. At the rest of the site-years, 
seed numbers were not modified. No effects of foliar B applied at R2 were observed on PC and PF. There was a foliar $\mathrm{B}$ treatment $\mathrm{x}$ site-year interaction for OC. At one site-year, OC decreased 0.25 p.p, while at a different site-year it tended to increase by 0.275 p.p. $(\mathrm{P}=0.115)$. At the rest of the site-years, no effect of foliar B was observed on OC. Relationship between soybean yield $\left(\mathrm{kg} \mathrm{ha}^{-1}\right)$ and seed protein (percentage points) response to 1.25 $\mathrm{kg} \mathrm{ha}{ }^{-1} \mathrm{Zn}$ soil fertilization treatment in the Pampean region in Argentina during years 13/14 and 14/15 is depicted in Fig. 3.
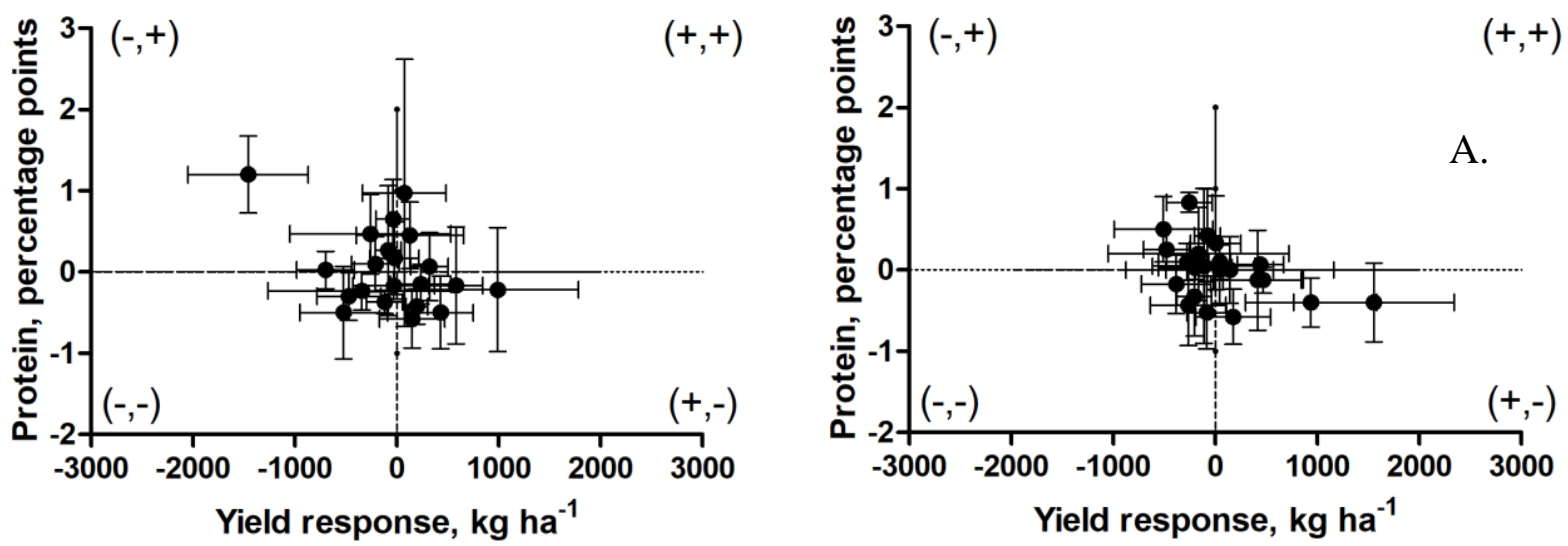

Fig. 2: Relationship between soybean yield $\left(\mathrm{kg} \mathrm{ha}^{-1}\right)$ and seed protein (percentage points) response to A.10 $\mathrm{kg} \mathrm{ha} \mathrm{h}^{-1} \mathrm{~N}$ foliar treatment and B.100 $\mathrm{g} \mathrm{ha}^{-1} \mathrm{~B}$ foliar treatment in the Pampean region in Argentina during years 14/15, 15/16 and 16/17. Each point represents a location with its standard error.

Fig. 3: Relationship between soybean yield $\left(\mathrm{kg} \mathrm{ha}^{-1}\right)$

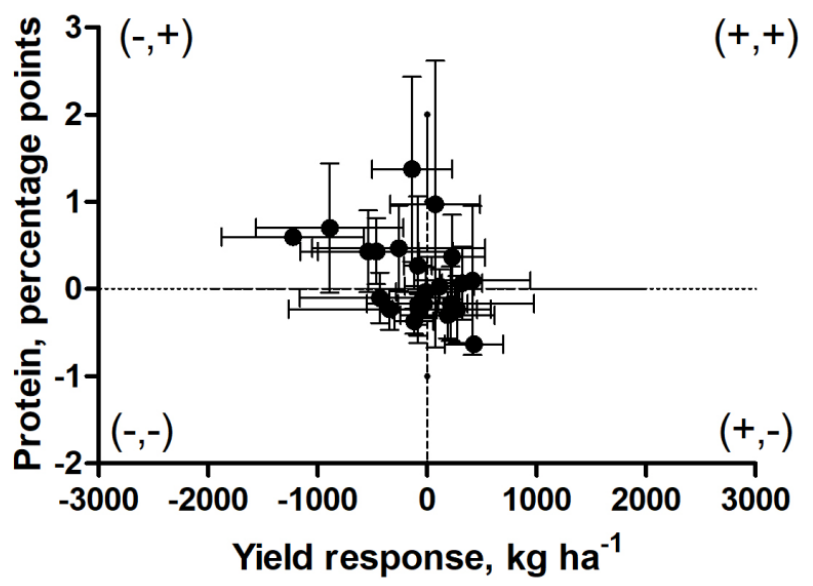

and seed protein (percentage points) response to $1.25 \mathrm{~kg}$ $\mathrm{ha}^{-1} \mathrm{Zn}$ soil fertilization treatment in the Pampean region in Argentina during years 13/14 and 14/15. Each point represents a location with its standard error.

\section{Discussion}

Yield response to $\mathrm{P}$ fertilization was consistent with soil P availability; in $83 \%$ of the site-years, soil analyses indicated P-Bray values under $14 \mathrm{mg}$ $\mathrm{kg}^{-1}$, which is considered a response threshold by Sucunza et al. (2018). Yield response to $S$ fertilization with a $\mathrm{P}$ base was not related to $\mathrm{S}$ $\mathrm{SO}_{4}{ }^{2-}$ soil levels or with soil organic matter content; this agrees with results observed by Salvagiotti et al. (2004) in experiments conducted on seven siteyears in the northern Pampean region.

There was a clear trend towards increasing yield and $\mathrm{PC}$ with the application of $\mathrm{P}$ and $\mathrm{S}$, especially when applied at a double rate (PP+SS). In effect, Aulakh et al. (1990), when evaluating soybean nutrition with $\mathrm{P}$ and $\mathrm{S}$ in a 3-year field experiment in India, found that a balanced $\mathrm{P}+\mathrm{S}$ fertilization resulted in maximum seed yield and enhanced the process of protein and oil synthesis. In our experiments, $\mathrm{P}+\mathrm{S}$ increased oil synthesis in $\mathrm{kg} \mathrm{ha}^{-1}$ due to an increase in yield but had no effect OC.

Protein concentration and PF increases due to $\mathrm{P}+\mathrm{S}$ application agree with Martínez and Cordone's (2015) observations in the Pampean region, as well as the positive response of OC at certain site-years and the negative response of $\mathrm{OC}$ at other site-years. In fact, Martínez and Cordone (2015) observed an even greater 
number of site-years with positive $\mathrm{PC}$ and $\mathrm{PF}$ responses to $\mathrm{P}$ and $\mathrm{S}$ fertilization compared to our study. The negative response of OC is similar to the response reported by $\mathrm{Haq}$ and Mallarino (2005) in 112 field trials in USA.

The lack of response to $\mathrm{Zn}$ fertilization possibly resulted from an optimal root edaphic exploration and from a sufficient water availability that increases mobilization and transfer of nutrients from the soil to the crop (Rodriguez-Navarro et al., 2011). Besides, Sainz Rosas (2013) stated that greater $\mathrm{Zn}$ fertilization responses are expected when organic matter content is low and $\mathrm{pH}$ values are high. In our study, very few sites matched with this classification since organic matter ranged from 1.6 to $5.9 \%$ and $\mathrm{pH}$ ranged from 5.6 to 7.2 .

Foliar B application at R2 had no significant effect on yield, PC, OC or PF, possibly because, in most site-years, soil available B was close or above soybean sufficiency levels reported by several authors (Gupta et al., 1985; Datta et al., 1994; Cox and Kamprath, 1972). Only a slight increase in seed weight was found when foliar B was applied, which was also observed by Gambaudo et al. (2010) after applying foliar B in $\mathrm{R}_{3}$. In contrast to our study, Fontanetto et al. (2009) observed yield increases due to an enhanced pod set resulting from the application of $150 \mathrm{~g} \mathrm{~B} \mathrm{ha}^{-1}$ in R2-R3.

The lack of PC and OC response to foliar B was also observed by Fontanetto et al. (2009). However, in a glasshouse experiment, Bellaloui et al. (2019), observed an increase in nodule biomass, grain weight, yield and PC and a decrease in OC due to foliar B application in R2 working with potted Mollic Hapludalf soils brought from a field with an average $0.72 \mathrm{mg} \mathrm{kg}^{-1}$ soil available B. No consistent effects were found on the studied variables with the foliar application of $10 \mathrm{~kg} \mathrm{ha}^{-1} \mathrm{~N}$ at $\mathrm{R} 5$; similar results were also observed by Moreira et al. (2017). On the contrary, Poole et al. (2010) applied foliar $\mathrm{N}$ solutions at $\mathrm{R}_{5}-\mathrm{R}_{7}$ and observed seed weight decreases, seed PC increases and OC decreases.

\section{Conclusion}

Phosphorus and $\mathrm{P}+\mathrm{S}$ replacement rate fertilization produced a significant soybean yield increase, and a double $\mathrm{P}+\mathrm{S}$ rate application produced an even greater yield response. These treatments increased PC in many site-years while in most site-years where $\mathrm{PC}$ increased $\mathrm{OC}$ decreased. $\mathrm{P}$ and $\mathrm{P}+\mathrm{S}$ simple and double rate treatments slightly increased PF. Pre-plant soil-applied Zn and foliar $\mathrm{N}$ and $\mathrm{B}$ applications had no effects on the studied variables. The foliar $\mathrm{N}$ treatment even caused phytotoxicity at some site-years, especially with rates above $10 \mathrm{~kg} \mathrm{~N} \mathrm{ha}^{-1}$.

This study shows that soybean yield and quality can be increased through agronomic practices such as fertilization with $\mathrm{P}$ and $\mathrm{S}$, while the role of $\mathrm{N}$ and micronutrients over these factors remains unclear. A proper fertilization strategy could help increase farmers' incomes and milling industry competitiveness. Further research on protein building processes; particularly the effect of $\mathrm{P}$ and $\mathrm{S}$ nutrition on BNF and the contribution of BNF to seed protein concentration are needed to elucidate the macronutrient dynamics in the soybean plant metabolism.

\section{Acknowledgement}

This study was partially supported by Bunge of Argentina, the Rosario Board of Trade and the Catholic University of Argentina (UCA). The experiments were conducted by students of the Department of Engineering and Agricultural Sciences of UCA as part of their undergraduate thesis. The authors also thank Helena RimskiKorsakov for her valuable suggestions.

\section{Conflict of interest statement}

Authors declare that they have no conflict of interest.

\section{References}

Allison, L.E., Bernstein, L., Bower, C.A., Brown, J.W., Fireman, M., Hatcher, J.T., Hayward, H.E., Pearson, G.A., Reeve, R.C., Richards, L.A., Wilcox, L.V., 1977. Métodos para caracterizar un suelo. In: L.A. Richards (Ed.), Diagnóstico y Rehabilación de Suelos Salinos y Sódicos. LimusaMéx. p. 172.

Aulakh, M.S., Pasricha, N.S., Azad, A.S., 1990. Phosphorus-sulphur interrelationships for 
soybeans on $\mathrm{P}$ and $\mathrm{S}$ deficient soil, Soil Sci. 150, 705-709.

Aytaç, S., Çirak, C., Özçelik, H., 2007. Foliar zinc application on yield and quality characters of soybean. Asian J. Chem. 19, 2410-2418.

Barker, D.W., Sawyer, J.E., 2005. Nitrogen application to soybean at early reproductive development. Agron. J. 97, 615-619.

Bellaloui, N., Reddy, K.N., Gillen, A.M., Abel, C.A., 2010. Nitrogen metabolism and seed composition as influenced by foliar boron application in soybean. Plant Soil. 336, 143-155.

Bray, R.H., Kurtz, L.T., 1945. Determination of total, organic and available forms of phosphorus in soil. Soil Sci. 59 (1), 39-45.

Carciochi, W.D., Divito, G.A., Reussi Calvo, N.I., Echevería, H.E., 2015. Qué sabemos del diagnóstico de azufre en los cultivos de la región Pampeana Argentina? Informaciones Agronómicas de Hispanoamérica. 18, 22-28.

Correndo, A.A., Rubio, G., Ciampitti, I., García, F.O., 2012. Dinámica del potasio en molisoles de la región Pampeana norte. In: XIX Congreso Latinoamericano de la Ciencia Del Suelo, XXIII Congreso Argentino La Ciencia Del Suelo.

Cox, F.R., Kamprath, E.J., 1972. Micronutrient soil test. In: Mortvedt, J.J., Giordano, P.N., Lindsay, W.L. (Eds.), Micronutrients in Agriculture. Soil Science Society of America, Madison, WI. pp. 289-317.

Cuniberti, M., Herrero, R., 2018. Problemática de la baja proteína de la soja. In: Soja. Información Actualizada Técnica En Línea. INTA Ed. 9-13.

Dardanelli, J.L., Balzarini, M., Martínez, M.J., Cuniberti, M., Resnik, S., Ramunda, S.F., Herrero, R., Baigorri, H., 2006. Soybean maturity groups, environments, and their interaction define mega-environments for seed composition in Argentina. Crop Sci. 46 (5), 1939-1947.

Datta, S.P., Kumar, A., Singh, R.P., Sarkar, A.K., 1994. Critical Limit of Available Boron for Soybean in Acid Sedentary Soils of Chotanagpur Region. J. Indian Soc. Soil Sci. 42, 93-96.

Díaz-Zorita, M., Grosso, G., Fernández-Canigia, M., Duarte, G., 1999. Efectos De La Ubicacion De Un Fertilizante Nitrógeno En Siembra
Directa En La Region De La Pampa Arenosa. Ciencia Del Suelo. 17, 62-65.

Divito, G.A., Sadras, V.O., 2014. How do phosphorus, potassium and sulphur affect plant growth and biological nitrogen fixation in crop and pasture legumes? A metaanalysis. F. Crop. Res. 156, 161-171.

Fehr, W.R., Caviness, C.E., 1977. Stages of soybean development. Iowa State University. Agricultural and Home Economics Experimental Station. http://lib.dr.iastate.edu/ specialreports $/ 87$.

Ferraris, J., Traficante, P., Tortorielo, A., 2015. Fertilización fósforo-azufrada en secuencias de soja continua. Estrategias basadas en dosis, localización y momentos de aplicación. Informaciones Agronómicas de Hispanoamérica. 5, 14-19.

Fontanetto, G., Keller, O., Albrecht, J., 2009. Efecto de la fertilización foliar con boro y nitrógeno sobre el cultivo de soja. Campaña 2008/o9. In: Inf. Técnica Cultiv. Verano. Campaña 2009. pp. 115-123.

Gambaudo, S., Racca Madoery, S.M., Fontanetto, H., 2010. Respuesta al agregado de micronutrientes en el cultivo de soja en suelos de diferente aptitud agrícola. Informaciones Agronómicas. 910, 1-4.

García, F.O., Ciampitti, I.A., Baigorri, H., 2009. La Nutrición del cultivo de Soja. In: García, F.O., Ciampitti, I.A. (Eds.), Manejo Del Cultivo de Soja, Agroeditor, Buenos Aires, Argentina. pp. 33-73.

Ghasemian, V., Ghalavand, A., Pirzad, A., 2010. The Effect of Iron, Zinc and Manganese on Quality and Quantity of Soybean Seed. J. Phytol. 2, 73-79.

Gupta, W.N. U.C., Jame, Y.W., Campbell, C.A., Leyshon, A.G., 1985. Boron toxicity and deficiency: A review. Can. J. Soil Sci. 65, 381409.

Gutierrez Boem, F.H., Prystupa, P., Alvarez, C.R., 2006. Comparación de dos redes de ensayos de fertilización fosforada de soja en la región Pampeana. Informaciones Agronómicas de Hispanoamérica. 6-8.

Haq, M.U., Mallarino, A.P., 2005. Response of soybean grain oil and protein concentrations to foliar and soil fertilization. Agron. J. 97, 910-918. 
Israel, D.W., 1987. Investigation of the Role of Phosphorus in Symbiotic Dinitrogen Fixation. Plant Physiol. 84, 835-840.

Kane, M. V., Steele, C.C., Grabau, L.J., MacKown, C.T., Hildebrand, D.F., 1997. Early-maturing soybean cropping system: III. Protein and oil contents and oil composition. Agron. J. 89, 464-469.

Lindsay, W.L., Norvell, W.A., 1978. Development of a DTPA soil test for zinc, iron, manganese and copper. Soil Sci. Soc. Am. J. 42, 421-428.

Lisle, L., Lefroy, R., Anderson, G., Blair, G., 1994. Methods for the measurement of sulphur in plant and soils. Sulphur Agric. 18, 45-54.

Marbán, L. Métodos de extracción y determinación de nitratos en suelos. Parte II. In: V.L. Marbán, S. Ratto (Eds.), Tecnologías de Análisis de Suelos, Asociación Argentina de la Ciencia del Suelo. pp. 131-138.

Marschner, H., 1995. Mineral Nutrition of Higher Plants. Academic P, San Diego.

Martínez, F., Cordone, G., 2015. Impacto de la fertilización en soja sobre la calidad del grano. Informaciones Agronómicas de Hispanoamérica. 18, 17-21.

Moreira, A., Moraes, L.A.C., Schroth, G., Becker, F.J., Mandarino, J.M.G., 2017. Soybean yield and nutritional status response to nitrogen sources and rates of foliar fertilization. Agron. J. 109, 629-635.

Murphy, J., Riley, H.P., 1962. A modified single solution method for the determination of phosphate in natural waters. Anal. Chim. Acta. 27, 31-36.

Nelson, D.W., Sommers, E., 1982. Total carbon, organic carbon and organic matter. In: A.L. Page (Ed.), Methods Soil Analysis, Part 2. Agronomy. pp. 534-579.

Panse, K., 2010. Effecty of N, P and Zn levels on growth and yield soybean ((Glycine max (L.) Merrill) under rainfed condition. JNKVV.

Peech, M., 1965. Method for soil pH in water. Hydrogen-ion activity. In: Method Soil Anal. Part 2. Chem. Microbiol. Prop., Black, California. pp. 915-926.

Poole, W.D., Randall, G.W., Ham, G.E., 2010. Foliar Fertilization of Soybeans. I. Effect of Fertilizer Sources, Rates, and Frequency of Application. Agron. J. 75, 195.

Prystupa, P., Salvagiotti, F., Ferraris, G.,
Gutierrez Boem, F.H., Elisei, J., Couretot, L., 2004. Efecto de la fertilización co fósforo, azufre y potasio en cultivos de maíz en la pampa ondulada. Informaciones Agronómicas de Hispanoamérica. 23.

Richter, M., Conti, M., Maccarini, G., 1982. Mejoras en la determinación de cationes intercambiables y capacidad de intercambio catiónico en los suelos. Revista de la Faculta de Agronomía. 3, 145-155.

Rodríguez-Navarro, D.N., Margaret Oliver, I., Albareda Contreras, M., Ruiz-Sainz, J.E., 2011. Soybean interactions with soil microbes, agronomical and molecular aspects. Agron. Sustain. Dev. 31, 173-190.

Ronis, D.H., Sammons, D.J., Kenworthy, W.J., Meisinger, J.J., 1985. Heritability of Total and Fixed N Content of the Seed in Two Soybean Populations. Crop Sci. 25, 1-4

Rotundo, J.L., Westgate, M.E., 2009. Metaanalysis of environmental effects on soybean seed composition. F. Crop. Res. 110, 147-156

Sainz Rozas, H., Eyherabide, M., Echeverría, H.E., Barbieri, P., Angelini, H., Larrea, G.E., Ferraris, G.N., Barraco, M., 2013 ¿Cuál es el estado de la fertilidad de los suelos argentinos? Simposio de Fertilidad. 62-72. http://ruralnet.com.ar/wp-content/uploads /2017/10/inta.estado-fertilidad-suelos-argen tinos.pdf.

Salvagiotti, F., Cassman, K.G., Specht, J.E., Walters, D.T., Weiss, A., Dobermann, A., 2008. Nitrogen uptake, fixation and response to fertilizer $\mathrm{N}$ in soybeans : A review Nitrogen uptake, fixation and response to fertilizer $\mathrm{N}$ in soybeans: A review. F. Crop. Res. 108, $1-13$.

Salvagiotti, F., Gerster, G., Bacigaluppo, S., Castellarín, J., Galarza, C., González, N., Gudelj, V., Novello, O., Pedrol, H., Vallone, P., 2004. Direct and Residual Effects of phosphorus and sulfur on double cropped soybean. Ciencia Del Suelo. 22, 92-101.

Sillanpaa, M., 1982. Micronutrients and the nutrient status of the soils: A global study, FAO, Rome.

Sucunza, F.A., Gutierrez Boem, F.H., Garcia, F.O., Boxler, M., Rubio, G., 2018. Long-term phosphorus fertilization of wheat, soybean and maize on Mollisols: Soil test trends, 
critical levels and balances, Eur. J. Agron. 96, 87-95.

Sulieman, S., Van Ha, C., Schulze, J., Tran, L.S.P., 2013. Growth and nodulation of symbiotic Medicago truncatula at different levels of phosphorus availability. J. Exp. Bot. 64, 2701-2712.

Thibodeau, P.S., Jaworski, E.G., 1975. Patterns of nitrogen utilization in the soybean. Planta. 127 (2), 133-147.

\section{How to cite this article:}

Davérède, I. C., Míguez, F. H., Borracci, A. A., 2019. Phosphorus, nitrogen, sulfur, boron and zinc fertilization effects on soybean yield and quality. Int. J. Curr. Res. Biosci. Plant Biol. 6(11), 9-21.

doi: https://doi.org/10.20546/ijcrbp.2019.611.002 